\title{
KRITERIA HUJAN YANG BERHUBUNGAN DENGAN KEJADIAN MALARIA DI KABUPATEN OKU SELATAN TAHUN 2019
}

\author{
Maya Arisanti ${ }^{*}$, Rizki Nurmaliani ${ }^{1}$ \\ ${ }^{1}$ Balai Penelitian dan Pengembangan Kesehatan Baturaja \\ Jl. A.Yani KM.7 Kemelak Baturaja, 32111, Kabupaten Ogan Komering Ulu, Sumatera Selatan, Indonesia
}

\begin{abstract}
Malaria still become a health problem in Indonesia. To overcome the problem of malaria, the government has launched elimination program of malaria. The high number of malaria cases is related to the environmental and climate change where the rainy season is longer. The rain has caused increasing malaria vector breeding grounds. Data used in this paper are secondary data from the Office of Health and the Central Statistics Agency for OKU Selatan in 2019. Data were analyzed using statistical tests to determine correlations and effects. The incidence of malaria a lot and for a long time in OKU Selatan in 2019 was highest in February, with 60 cases, 409.23 $\mathrm{mm}$ of rainfall and 18 days of rain. The results of the data analysis showed that rain with the criteria rainfall and the number of rainy days had the higest mean rank number compared to other rainfall criteria. The significant value showed a number below 0,05, so it could be said that there were a relationship between malaria incidence and rainfall criteria in OKU Selatan regency.
\end{abstract}

Keywords: Rainfall, malaria incidence, OKU Selatan Regency.

\section{RAIN CRITERIA ASSOCIATED WITH THE INCIDENCE OF MALARIA IN OKU SELATAN REGENCY IN 2019}

\begin{abstract}
Abstrak
Malaria masih menjadi masalah kesehatan di Indonesia. Untuk mengatasi masalah malaria pemerintah telah mencanangkan tentang program eliminasi malaria. Masih tingginya kasus malaria berkaitan dengan adanya perubahan lingkungan dan iklim dimana musim penghujan menjadi lebih panjang. Hujan menyebabkan bertambahnya tempat perkembangbiakan nyamuk vektor malaria. Data dalam penulisan ini merupakan data dari Dinas Kesehatan dan Badan Pusat Statistik Kabupaten OKU Selatan tahun 2019. Data dianalisis menggunakan pengujian statistik untuk mengetahui hubungan kriteria hujan dengan kejadian malaria di Kabupaten OKU Selatan pada tahun 2019. Kejadian malaria, curah hujan, dan jumlah hari hujan paling tinggi terjadi pada Bulan Februari yaitu 60 kasus dengan curah hujan 409,23 mm dan 18 hari hujan. Hasil analisis data menunjukkan kriteria banyak hujan dan lama memiliki angka mean rank yang paling tinggi dibandingkan dengan kriteria hujan lainnya. Nilai kemaknaan menunjukkan angka dibawah 0,05 sehingga dapat dikatakan bahwa ada hubungan antara kejadian malaria dengan kriteria hujan di Kabupaten OKU Selatan.
\end{abstract}

Kata kunci : Curah hujan, kejadian malaria, Kabupaten OKU Selatan.

Naskah masuk: 01 Juli 2020; Review: 28 Juli 2020; Layak Terbit: 10 Desember 2020

*Alamat korespondensi penulis pertama: e-mail: maya_arisanti@yahoo.co.id; Telp: (0735) 325303 


\section{LATAR BELAKANG}

Malaria merupakan salah satu penyakit menular yang masih menjadi masalah kesehatan di Indonesia karena dapat menyebabkan kematian terutama pada kelompok risiko tinggi yaitu bayi, balita, dan ibu hamil. Malaria pada manusa disebabkan oleh parasit Plasmodium falciparum, $P$. vivax, $P$. Malariae, dan $P$. ovale yang ditularkan melalui gigitan nyamuk Anopheles. Beberapa tahun terakhir, di Indonesia juga ditemukan juga penularan malaria yang disebabkan $P$. knowlesi. ${ }^{1}$ Kasus malaria di Indonesia pada tahun 2019 sebanyak 250.644 kasus yang tersebar di seluruh provinsi. Kasus malaria di Provinsi Sumatera Selatan pada tahun 2019 adalah sebanyak 602 kasus dan Kabupaten OKU Selatan sendiri merupakan salah satu kabupaten endemis malaria di Provinsi Sumatera Selatan. ${ }^{1}$

Dalam pertemuan World Health Assembly (WHA) ke 60 tahun 2007 telah menghasilkan komitmen global tentang eliminasi malaria untuk semua negara termasuk Indonesia. Target Indonesia adalah tahun 2030 mencapai eliminasi malaria. Capaian eliminasi di Indonesia pada tahun 2019 sebanyak 300 kabupaten/kota. ${ }^{1}$ Kabupaten/kota dapat diusulkan untuk memperoleh sertifikasi eliminasi malaria apabila memenuhi kriteria Slide Positivity Rate $(\mathrm{SPR})<5 \%$, Annual Parasite Incidence (API)<1 per 1000 penduduk dan tidak ada kasus penularan setempat/indigenous selama tiga tahun terakhir. $^{2}$ Angka SPR dan API untuk Kabupaten Ogan Komering Ulu Selatan (OKU Selatan) sendiri telah memenuhi kriteria untuk dilakukannya sertifikasi eliminasi malaria, tetapi kasus dengan penularan setempatnya masih tinggi. ${ }^{3}$

Tingginya kasus malaria di Indonesia sangat berkaitan erat dengan beberapa hal antara lain adanya perubahan lingkungan yang berakibat meluasnya tempat perindukan nyamuk penular malaria, mobilitas penduduk yang cukup tinggi, dan perubahan iklim yang menyebabkan musim hujan lebih panjang dari musim kemarau. ${ }^{4}$ Adanya perubahan lingkungan dan iklim akan berdampak besar terhadap biologi, distribusi, dan kepadatan populasi vektor pada waktu dan tempat tertentu. Pergantian musim akan berpengaruh langsung maupun tidak langsung terhadap vektor malaria. ${ }^{5}$ Penelitian di Tanah Bumbu menyatakan kasus malaria yang meningkat di Bulan Oktober hingga Bulan Juni menunjukkan bahwa faktor iklim menjadi salah satu yang mempengaruhi dimana Bulan Oktober-Juni merupakan bulan basah (hujan). ${ }^{6}$ Hujan menyebabkan naiknya kelembaban nisbi udara dan curah hujan yang tinggi mengakibatkan banyak munculnya genangan air yang digunakan nyamuk sebagai tempat berkembangbiak. Bertambahnya tempat perkembangbiakan nyamuk dapat meningkatkan kejadian malaria. Penelitian di Kabupaten Lampung Selatan menunjukkan bahwa keberadaan tempat perindukan nyamuk berhubungan dengan kejadian malaria dimana orang yang bertempat tinggal dekat dengan tempat perindukan nyamuk berisiko terkena penyakit malaria sebesar 6,127 kali dibandingkan dengan mereka yang bertempat tinggal jauh dari tempat perindukan. ${ }^{7}$ Penelitian di Kabupaten Bintan menyatakan bahwa pada tahun 2007 terlihat pola dimana saat insiden malaria cenderung meningkat, curah hujan juga tinggi pada bulan tersebut yaitu mencapai 639 mm. $^{8}$ Penelitian lain di Bengkulu juga menyatakan bahwa ada hubungan antara curah hujan, jumlah hari hujan dengan kejadian malaria. ${ }^{9}$

Masih ditemukannya kasus penularan setempat di Kabupaten OKU Selatan disebabkan masih ditemukannya tempat berkembangbiak nyamuk vektor malaria. Salah satu faktor yang mempengaruhi tempat perkembangbiakan nyamuk Anopheles sundaicus adalah air, curah hujan berperan pada tersedianya air sebagai tempat perindukan nyamuk. ${ }^{10}$ Perubahan iklim global dapat berpengaruh terhadap perkembangbiakan vektor penyakit sehingga meningkatkan kejadian penyakit yang ditularkan nyamuk seperti malaria. ${ }^{10}$ Tujuan artikel ini membahas hubungan curah hujan dan jumlah hari hujan terhadap kejadian malaria di Kabupaten OKU Selatan.

\section{METODE}

Penelitian ini bersifat analitik dengan menggunakan beberapa data sekunder tahun 2019. Data kasus malaria diperoleh dari Dinas Kesehatan Kabupaten OKU Selatan. Data curah hujan dan hari hujan diperoleh dari data Badan Pusat Statistik Kabupaten OKU Selatan. 
Data-data tersebut kemudian dianalisis dengan menggunakan pengujian statistik untuk mengetahui kriteria hujan dengan kejadian malaria. Kejadian malaria dihitung dengan menggunakan rumus ${ }^{4}$ :

$$
\begin{aligned}
& \text { Mopi }(\text { Monthly } \\
& \text { Parasite Incidence) }
\end{aligned}=\frac{\text { Jumlah kasus perbulan }}{\text { jumlah penduduk }}
$$

Jumlah penduduk yang digunakan untuk menghitung Mopi adalah jumlah penduduk pertengahan tahun yaitu 415.970 jiwa. Data curah hujan per hari dan jumlah hari hujan dikategorikan menjadi dua kategori yaitu banyak dan sedikit, lama dan sebentar. Kemudian kedua variabel tersebut dikombinasikan menjadi satu variabel yaitu variabel kriteria hujan. Dikarenakan data Mopi, curah hujan, dan jumlah hari hujan berdistribusi tidak normal, maka uji statistik yang digunakan adalah uji statistik non parametrik. Uji yang digunakan untuk mengetahui hubungan kriteria hujan dengan kejadian malaria adalah Uji Kruskal Wallis Test $^{11}$. Hipotesis awal $(\mathrm{H} 0)$ yang digunakan adalah tidak terdapat hubungan kriteria hujan dengan kejadian malaria dan hipotesis alternatifnya adalah terdapat hubungan kriteria hujan dengan kejadian malaria. Jika nilai kemaknaan ( $p$ value) $<0,05$ maka kesimpulan statistik terhadap hipotesis yang diajukan adalah menolak $\mathrm{HO}$ atau ada hubungan kriteria hujan dengan kejadian malaria.

\section{HASIL}

Kabupaten OKU Selatan merupakan salah satu kabupaten yang masih menjadi daerah endemis malaria rendah dengan nilai API kurang dari 1\%o. Berdasarkan data Dinas Kesehatan Kabupaten OKU Selatan jumlah kasus malaria pada tahun 2019 adalah 336 kasus positif yang tersebar di seluruh kecamatan di Kabupaten OKU Selatan. Jumlah Kasus malaria paling tinggi terjadi pada Bulan Februari yaitu 60 kasus $(0,14 \%)$ dan mengalami perubahan yang fluktuatif pada bulan-bulan berikutnya. Jumlah curah hujan dan jumlah hari hujan per bulan di Kabupaten OKU Selatan tahun 2019 berkisar 28,98409,23 mm dan 2-18 hari, sedangkan jumlah curah hujan perhari berkisar 14,49-30,08 $\mathrm{mm} / \mathrm{hari}$.

Tabel 1. Angka Mopi, Jumlah Curah Hujan, Jumlah Hari Hujan, dan Jumlah Curah Hujan perhari Kabupaten OKU Selatan Tahun 2019

\begin{tabular}{|c|c|c|c|c|c|}
\hline Bulan & $\begin{array}{l}\text { Jumlah } \\
\text { Kasus }\end{array}$ & $\begin{array}{c}\text { Mopi } \\
\text { (per seribu } \\
\text { penduduk) }\end{array}$ & $\begin{array}{c}\text { Jumlah } \\
\text { Curah Hujan } \\
(\mathrm{mm})\end{array}$ & $\begin{array}{c}\text { Jumlah } \\
\text { Hari Hujan } \\
\text { (hari) }\end{array}$ & $\begin{array}{c}\text { Jumlah } \\
\text { Curah Hujan } \\
\text { per Hari } \\
\text { (c/d) }\end{array}$ \\
\hline & $a$ & $\mathrm{~b}$ & $\mathrm{C}$ & $d$ & $\mathrm{e}$ \\
\hline Januari & 51 & 0,12 & 362,60 & 17 & 21,33 \\
\hline Februari & 60 & 0,14 & 409,23 & 18 & 22,74 \\
\hline Maret & 51 & 0,12 & 238,80 & 12 & 19,90 \\
\hline April & 27 & 0,06 & 252,63 & 14 & 18,05 \\
\hline Mei & 34 & 0,08 & 153,75 & 7 & 21,96 \\
\hline Juni & 29 & 0,07 & 156,13 & 8 & 19,52 \\
\hline Juli & 33 & 0,08 & 146,53 & 6 & 24,42 \\
\hline Agustus & 19 & 0,05 & 90,25 & 3 & 30,08 \\
\hline September & 17 & 0,04 & 28,98 & 2 & 14,49 \\
\hline Oktober & 11 & 0,03 & 45,13 & 3 & 15,04 \\
\hline November & 4 & 0,01 & 123,33 & 7 & 17,62 \\
\hline Desember & 0 & 0,00 & 303,25 & 13 & 23,33 \\
\hline Total & 336 & 0,81 & 192,55 & 9 & 21,39 \\
\hline
\end{tabular}

Sumber : a adalah data dari Dinas Kesehatan Kabupaten OKU Selatan, c dan d adalah data dari Badan Pusat Statistik OKU Selatan Tahun 2019 
Tabel 2. Hasil Uji Kruskal Wallis Peringkat Kriteria Hujan terhadap Mopi di Kabupaten OKU Selatan Tahun 2019

\begin{tabular}{llrc}
\hline & Kriteria Hujan & $\mathrm{N}$ & Mean Rank \\
\hline Mopi perbulan & banyak dan lama & 111 & 269,28 \\
& banyak dan sebentar & 85 & 118,87 \\
& sedikit dan lama & 79 & 169,58 \\
& sedikit dan sebentar & 61 & 52,87 \\
\hline & Total & 336 & \\
\hline${ }^{*}$ Asimp. Sig 0,000 & & &
\end{tabular}

Angka mean rank pada tabel 2 menunjukkan peringkat rata-rata masingmasing kriteria hujan. Hujan dengan kriteria banyak dan lama memiliki angka mean rank yang paling tinggi dibandingkan dengan kriteria hujan lainnya. Nilai Asimp. Sig menunjukkan angka dibawah 0,05 sehingga dapat dikatakan bahwa ada hubungan antara kejadian malaria (Mopi) dengan kriteria hujan.

\section{BAHASAN}

Malaria merupakan penyakit yang ditularkan vektor dan masih menjadi masalah kesehatan masyarakat di Indonesia dengan angka kesakitan dan kematian yang cukup tinggi dan berpotensi menimbulkan kejadian luar biasa (KLB). ${ }^{5}$ Kabupaten OKU Selatan sendiri termasuk ke dalam kabupaten dengan endemisitas malaria rendah yaitu kurang $1 \%$ yaitu $0,81 \%$ pada tahun 2019. Pada kabupaten endemis rendah dilakukan strategi pembebasan/eliminasi yang bertujuan untuk menghilangkan kasus penularan setempat/indigenous. ${ }^{12}$ Berdasarkan data Dinas Kesehatan Kabupaten OKU Selatan, kasus malaria yang terjadi selama tahun 2019 sebagian besar merupakan kasus penularan setempat yaitu 334 kasus. Sama halnya dengan data dua tahun sebelumnya dimana kasus indigenous masih banyak terjadi di Kabupaten OKU Selatan. ${ }^{3}$ Indikasi masih terjadinya penularan setempat adalah ditemukan vektor atau tersangka vektor dan tempat perindukan potensial di wilayah tersebut. Penelitian yang telah dilakukan di Kabupaten OKU Selatan ditemukan dua ekor Anopheles sinensis dan satu ekor An. separatus. ${ }^{13}$ Penelitian yang dilakukan Yahya dkk juga menemukan tempat perkembangbiakan nyamuk Anopheles di Desa Jagaraga berupa lubang galian batu bata, sawah, aliran air, kobakan, dan aliran anak sungai. ${ }^{14}$

Penyakit malaria merupakan penyakit berbasis lingkungan yang dipengaruhi oleh lingkungan fisik, biologi, dan sosial budaya. Ketiga faktor tersebut akan saling mempengaruhi kejadian malaria di daerah penyebarannya. Beberapa faktor yang menyebabkan tingginya angka kesakitan malaria antara lain adanya perubahan iklim, keadaan sosial-ekonomi, dan perilaku masyarakat. ${ }^{5}$ Iklim merupakan salah satu komponen dari lingkungan fisik yang merupakan gabungan beberapa faktor seperti temperatur, kelembaban nisbi, curah hujan, pencahayaan, dan angin yang berpengaruh terhadap penyebaran atau distribusi nyamuk Anopheles pada daerah tertentu.

Pada penelitian ini, rata-rata curah hujan di Kabupaten OKU Selatan pada tahun 2019 adalah 192,55 mm yang tergolong kedalam kategori curah hujan normal menengah. ${ }^{15}$ Curah hujan dan jumlah hari hujan maksimum di Kabupaten OKU Selatan pada tahun 2019 terjadi pada Bulan Februari dimana pada bulan ini jumlah kasus malaria juga merupakan jumlah kasus tertinggi. Pada penelitian ini didapatkan adanya hubungan antara kriteria curah hujan dengan kejadian malaria dimana hujan dengan kriteria banyak dan lama angka kasus per bulannya paling tinggi. Intensitas hujan yang banyak dan lama dapat menyebabkan munculnya genangan-genangan air yang bisa menjadi tempat perkembangbiakan nyamuk yang bersifat sementara. Penelitian di Kabupaten Kapuas Hulu menyatakan terdapat hubungan yang kuat antara curah hujan, 
suhu maksimum, suhu minimum, kelembaban maksimum, kelembaban minimum terhadap tingkat kejadian malaria. ${ }^{16}$ Penelitian di Sumba Barat Daya menyatakan bahwa ada hubungan yang signifikan antara infeksi Plasmodium falciparum dan curah hujan. ${ }^{17}$ Berbeda dengan penelitian lain yang menunjukkan bahwa tidak ada hubungan bermakna antara kejadian malaria dengan curah hujan. ${ }^{18}$ Penelitian di Selayar, menyatakan curah hujan dan hari hujan tidak memiliki hubungan korelasi bermakna dengan kejadian malaria. ${ }^{19}$

Hubungan kriteria hujan dengan kejadian malaria tidak terlepas dari peran nyamuk Anopheles sebagai vektor penular malaria. Daerah tropis seperti di Indonesia kepadatan (densitas) nyamuk tinggi biasanya terjadi pada musim hujan. Hujan akan mempengaruhi naiknya kelembaban nisbi udara dan menambah jumlah tempat perkembangbiakan nyamuk. ${ }^{5}$ Musim hujan sangat mempengaruhi terjadinya tempat perkembangbiakan nyamuk, pada awal musim hujan populasi nyamuk akan meningkat, namun pada musim penghujan dengan intensitas tinggi dengan waktu lama maka tempat berkembangbiak nyamuk yang ada akan terbawa arus. ${ }^{20}$ Penelitian di Lampung menyatakan bahwa ada hubungan bermakna indeks curah hujan dengan kepadatan nyamuk Anopheles artinya kepadatan nyamuk Anopheles disebabkan oleh curah hujan. ${ }^{21}$ Penelitian di Distrik Heram Jayapura didapatkan hasil bahwa curah hujan mempengaruhi sebaran habitat positif larva nyamuk Anopheles $s p p .^{22}$ Terdapat hubungan langsung antara hujan dan perkembangan larva nyamuk menjadi dewasa, besar kecilnya pengaruh tergantung pada jenis hujan, derasnya hujan, jumlah hari hujan, jenis vektor, dan jenis tempat perindukan. Hujan yang diselingi panas akan memperbesar kemungkinan berkembangbiaknya Anopheles. ${ }^{23}$ Banyaknya habitat perkembangbiakan nyamuk yang ditemukan berkorelasi positif dengan kejadian malaria dimana semakin banyak jumlah habitat perkembangbiakan larva Anopheles kejadian malaria cenderung meningkat. ${ }^{19}$ Dengan ditemukannya nyamuk Anopheles di suatu daerah mengindikasikan masih terjadinya kemungkinan penularan malaria di daerah tersebut.

\section{KESIMPULAN}

Kriteria hujan berhubungan dengan kejadian malaria di Kabupaten OKU Selatan. Kasus malaria paling tinggi terjadi pada bulan yang intensitas hujannya lama dan diperburuk jika hujannya berintensitas banyak. Kondisi ini menyebabkan munculnya genangan-genangan air sebagai tempat perkembangbiakan nyamuk.

\section{SARAN}

Perubahan iklim dapat menyebabkan semakin panjangnya musim hujan yang berdampak pada bertambahnya tempat perkembangbiakan nyamuk. Perlu peran aktif dan kerjasama antara masyarakat dengan pemerintah setempat. Penebaran ikan di sawah dan tempat yang berpotensi menjadi habitat nyamuk bisa dijadikan salah satu solusi untuk mengurangi populasi nyamuk. Selain itu, kegiatan kerja bakti membersihkan lingkungan juga bisa dilakukan secara rutin. Kegiatan ini diharapkan dapat mengurangi populasi nyamuk dan memutus penularan malaria.

\section{UCAPAN TERIMA KASIH}

Terima kasih disampaikan kepada Kepala Dinas Kesehatan Kabupaten OKU Selatan beserta staf, Kepala Balai Litbang Kesehatan Baturaja yang telah memfasilitasi dan membantu dalam penulisan artikel ini.

\section{KONTRIBUTOR PENULIS}

MA dan RN sebagai kontributor utama dalam penulisan ini yang bertanggung jawab pada konsep, analisis data, metodelogi, mengkaji hasil, penelusuran referensi, kesimpulan dan saran.

\section{DAFTAR PUSTAKA}

1. Kemenkes RI. Laporan Situasi Terkini Perkembangan Program Pengendalian Malaria Di Indonesia Tahun 2019. Vol 4247608. dirjen Pencegahan dan Pengendalian Penyakit Kemenkes RI; 2019.

2. Kemenkes RI. Petunjuk Teknik 
Penilaian Eliminasi Malaria Keputusan Dirjen $P 2 P$ Nomor: HK.02,02/IV/1813/2017. Ditjen P2P Kemenkes RI; 2017.

3. Arisanti M, Nurmaliani R. Situasi Pra Eliminasi Malaria di Kabupaten OKUS. J Bahana Kesehat Masy. 2019;3(1):5158.

4. Kementerian Kesehatan RI. Pedoman Manajemen Malaria. Ditjen PP dan PL Kemenkes RI; 2014.

5. Kemenkes RI. Pedoman Pengendalian Vektor Malaria. Ditjen PP dan PL Depkes RI; 2014.

6. Sulasmi S, Setyaningtyas DE, Rosanji A, Rahayu N. Pengaruh curah hujan, kelembaban, dan temperatur terhadap prevalensi Malaria di Kabupaten Tanah Bumbu Kalimantan Selatan. J Heal Epidemiol Commun Dis. 2017;3(1):2227. doi:10.22435/jhecds.v3i1.1794

7. Susanti F, Wantini S. Faktor-faktor yang Berhubungan Dengan Kejadian Malaria di Wilayah Kerja UPT Puskesmas Rajabasa Kecamatan Rajabasa Kabupaten Lampung Selatan. J Anal Kesehat. 2014;3(1).

8. Mardiana, Musadad DA. Pengaruh Perubahan Iklim Terhadap Insiden Malaria di Kabupaten Bintan Kepulauan Riau dan Kabupaten Banggai Sulawaesi Tengah. J Ekol Kesehat. 2012;11(1):52-62.

9. Gustina M, Jubaidi. Study Ekologi Hubungan Iklim Dengan Kejadian Malaria Di Kota Bengkulu Tahun 20112013. J Media Kesehat. 2015;8(1):5862.

10. Pratama GY. Nyamuk Anopheles Sp dan Faktor yang Mempengaruhi di Kecamatan Rajabasa, Lampung Selatan. J Major. 2015;4(1):20-27. http://juke.kedokteran.unila.ac.id/index. php/majority/article/view/496

11. Sujarweni VW. Statistik Untuk Kesehatan. Gava Media; 2015.

12. Kemenkes RI. Situasi Terkini Perkembangan Program Pengendalian Malaria Di Indonesia Tahun 2018. Kemenkes $\quad \mathrm{RI}$; 2018. http://www.malaria.id/p/buku-tahun2019.html.diunduh

13. Sitorus $H$, Santoso $S$, Budiyanto $A$, Ambarita LP, Hapsari N. Keanekaragaman Spesies Nyamuk di Wilayah Endemis Filariasis di Kabupaten Banyuasin dan Endemis Malaria di OKU Selatan. Balaba J Litbang Pengendali Penyakit Bersumber Binatang Banjarnegara. 2015;11(2):97-104. doi:10.22435/blb.v11i2.4450.97-104

14. Yahya, Pahlepi RI, Komaria RH, Asyati D, Oktavia Su. Kepadatan dan Keragaman Spesies Nyamuk di Desa Jagaraga Kecamatan Buana Pemaca dan Desa Sukajaya Kecamtan Buay Rawan Kabupaten Ogan Komering Ulu Selatan. J Vektor Penyakit. 2020;14(1):37-48. doi:10.1017/CBO9781107415324.004

15. BMKG. Normal Hujan Bulanan.; 2017. https://bmkgsampali.net/normal-hujanbulanan

16. Anindhita EK, Natalia D, Fitriangga A. Pengaruh pola perubahan cuaca terhadap tingkat kejadian malaria di Kabupaten Kapuas Hulu tahun 2013 dan 2014. J cerebellum. 2017;3(1):680688.

17. Mau F, Mulatsih. Hubungan Antara Curah Hujan dan Temperatur dengan Malaria di Kabupaten Sumba Barat Daya Provinsi Nusa Tenggara Timur Indonesia. Bul Penelit Kesehat. 2018;46(2):129-134.

doi:10.22435/bpk.v46i2.309

18. Nurmala EE. Dinamika Perubahan Unsur Iklim (Suhu, Kelembaban Dan Curah Hujan) Dan Kejadian Malaria Pada Penduduk Pandeglang. J Dunia Kesmas Vol. 2017;6(2):63-69.

19. Asnifatima A. Pola Kecenderungan Spasial Kejadian Malaria (Studi Kasus; Di Kabupaten Kepulauan Selayar Tahun 2011-2013). Hearty. 2017;5(1):1-12. doi:10.32832/hearty.v5i1.1051

20. Mardiana dan Perwitasari dalam Wayan N, Adnyana D, Wila W. Fauna Anopheles Sp Di Kabupaten Sumba 
Barat Daya. J Ekol Kesehat. 2011;11(3):211-219.

ttps://media.neliti.com/media/publicatio ns/82991-ID-fauna-anopheles-sp-dikabupaten-sumba-ba.pdf

21. Suwito, Hadi UK, Sigit SH, Sukowati S. Hubungan Iklim, Kepadatan Nyamuk Anopheles dan Kejadian Penyakit Malaria. J Entomol Indon. 2010;7(1):42-

53.

22. Tulak N, Handoko H, Hidayati R, Hadi UK, Hakim L. Karakteristik dan Distribusi Spasial Habitat Positif Larva Nyamuk Anopheles spp. Berdasarkan Curah Hujan. Media Kesehat Masy Indones. 2018;14(3):285. doi:10.30597/mkmi.v14i3.3307

23. Departemen Kesehatan RI. Modul I Epidemiologi Malaria. Direktorat Jenderal PPM dan PLP; 1999. 